\section{Dietary fat and risk of coronary heart disease in men}

\section{Studies quoted showed opposite of what is claimed}

EDITOR,-Alberto Ascherio and colleagues were unable to show a significant association between intake of saturated fatty acids (as percentage of energy) or of cholesterol and total myocardial infarction and coronary heart disease after appropriate adjustments. ${ }^{1}$ With saturated fatty acids they found a positive trend for fatal coronary heart disease but an inverse trend for all cases of myocardial infarction (fatal plus nonfatal). Thus these data indicate a clear inverse relation between saturated fatty acids and non-fatal myocardial infarction. The authors fail to comment on this surprising divergence.

From the numerous studies in the literature they quote "the evidence" for a direct association between intake of saturated fatty acids and risk of coronary heart disease-namely, four international comparisons and four prospective studies. But in fact these studies tend to show the opposite. In Scrimshaw and Guzman's study animal fat was not related to the degree of atherosclerosis. The two papers on Japanese emigrants reported no data on the relation between saturated fatty acids and coronary heart disease, although another analysis found that the cultural upbringing of the emigrants was far more important than their diet. ${ }^{2}$ In the seven countries study the association was seen in cross cultural analysis but not within the cohorts. In two of the four prospective studies, the Framingham study and the Ireland-Boston diet-heart study, the associations did not reach significance.

\section{Advice to authors}

We receive more letters than we can publish: we can currently accept only about one third. We prefer short letters that relate to articles published within the past four weeks. Letters received after this deadline stand less chance of acceptance. We also publish some "out of the blue" letters, which usually relate to matters of public policy.

When deciding which letters to publish we favour originality, assertions supported by data or by citation, and a clear prose style. Wit, passion, and personal experience also have their place.

Letters should have fewer than 400 words (please give a word count) and no more than five references (including one to the $B M \mathcal{F}$ article to which they relate); references should be in the Vancouver style. We welcome pictures.

Letters should be typed and signed by each author, and each author's current appointment and address should be stated. We encourage you to declare any conflict of interest.

Please enclose a stamped addressed envelope if you would like to know whether your letter has been accepted or rejected.

Letters will be edited and may be shortened.
In Goldbourt et als study there was an inverse trend between intake of saturated fatty acids (in $\mathrm{g} /$ day) and coronary heart disease, and data on intake of saturated fat as a percentage of energy were not reported. This leaves just one prospective study in the literature that directly related intake of saturated fatty acids to risk of coronary heart disease. ${ }^{3}$

Thus Ascherio and colleagues' results are in good agreement with the vast majority of data in the literature in showing no risk of coronary heart disease related to consumption of saturated fatty acids. It is time to realise that the diet-heart hypothesis as it relates to intake of saturated fatty acids and cholesterol can be upheld only if most observations are ignored and quotation bias is used. ${ }^{4}$

Finally, Ascherio and colleagues do not present any data on oleic acid, nor do they give their reason for withholding these data. This is all the more surprising since one of the authors (Willett) has claimed health benefits from consumption of olive oil-so far without sufficient evidence. ${ }^{5}$

NICOLAI WORM*

Dalandstrasse 8,

81927 Munich,

Germany

1 Ascherio A, Rimm EB, Giovannucci EL, Spiegelmann D Stampfer M, Willett WC. Dietary fat and risk of coronary heart disease in men: cohort follow up study in the United States. BMF 1996;313:84-90. (13 July.)

2 Marmot MG, Syme SL. Acculturation and coronary heart disease in Japanese-Americans. Am $\mathcal{F}$ Epidemiol 1976;104:22547.

3 McGee DL, Reed DM, Yano K, Kagan A, Tillotson J. Ten-year incidence of coronary heart disease in the Honolulu hear program: relationship to nutrient intake. $A m \mathcal{F}$ Epidemiol 1984;119:667-76.

4 Ravnskov U. Quotation bias in reviews of the diet-heart idea. $\mathcal{F}$ Clin Epidemiol 1995;48:713-9.

5 Willett WC, Sacks F, Trichopoulou A, Drescher G, Ferro-Luzzi A, Helsing E, et al. Mediterranean diet pyramid: a cultural model for healthy eating. Am $\mathcal{F}$ Clin Nutr 1995; 61 (suppl): 1402-6S.

${ }^{\star}$ Dr Worm occasionally works for the Central Marketing Agency for German agricultural products.

\section{Study gives clear message about diet}

EDIToR,-Alberto Ascherio and colleagues studied over 40000 health professionals to examine the association between fat intake and the incidence of coronary heart disease in men of middle age and older. ${ }^{1}$ Investigation into the influence of dietary fats on risk of heart disease has long been a contentious field, and the literature shows a quick response to the publication of new work. For example, after the publication of the paper by Law et al on cholesterol reduction and risk of ischaemic heart disease in $1994^{2}$ the $B M F$ published 10 letters commenting on the study.

If discussion of the minutiae of study design, results, analysis, etc is put aside then the message from Ascherio and colleagues' study is clear and simple: all middle aged and older men who want to reduce their risk of death from coronary heart disease must lower their intake of saturated fat and cholesterol while increasing the amount of n-3 fatty acids and fibre in their diets. Interestingly, these conclusions are similar to the information coming from intervention studies of Mediterranean diets, which have concluded that to reduce the risk of heart disease we must eat less meat (a major dietary source of saturated fat and cholesterol) and more fruit, cereals, and vegetables (sources of fibre). ${ }^{3}$ We could probably improve our risk profiles even further if we drank a glass of red wine with our meals. ${ }^{4}$

This excellent and easily available dietary treatment is unlikely to become common practice among the general public, because we now live in the age of the soft option. The west of Scotland coronary prevention study indicates that similar or perhaps even better results can be obtained by giving 3-hydroxy-3-methylglutaryl coenzyme A reductase inhibitors prophylactically. ${ }^{5}$ The pharmaceutical industry would have us believe that these drugs are the only way to combat cardiovascular disease, although this is clearly not the case.

Although a lower incidence of heart disease in the population would, in the long term, result in reduced costs to health services, an importan issue to consider is that prescribing these drugs takes responsibility for maintaining health away from the individual and lays it at the door of health professionals. Should already strained health services shoulder the burden of prescribing drugs prophylactically to those people who would rather take a pill than observe a healthier diet? Postdoctoral research fellow Department of Clinical Pharmacology and Therapeutics, Chelsea and Westminster Hospital, London SW10 9NH

Ascherio A, Rimm EB, Giovannucci EL, Spiegelman D, Stamfer $M$, Willett WC. Dietary fat and risk of coronary heart disease in men: cohort follow up study in the United States. BMf 1996;313:84-90. (13 July.)

2 Law MR, Wald NJ, Thompson SG. By how much and how quickly does reduction in serum cholesterol concentration lower risk of ischaemic heart disease? BMF 1994;308:36772.

3 De-Lorgeril M, Renaud S, Mamelle N, Salen P, Martin IL Monjaud I, et al. Mediterranean alpha-linolenic acid-rich diet in secondary prevention of coronary heart disease. diet in secondary preventi

4 Kushi LH, Lenart EB, Willett WC. Health implications of Mediterranean diets in light of contemporary knowledge. 2 . Meat, wine, fats, and oils. Am f Clin Nutr 1995;61 (suppl):1416-27S

Shepherd J, Cobbe SM, Ford I, Isles CG, Lorimer AR Macfarlane PW, et al. Prevention of coronary heart diseas with pravastatin in men with hypercholesterolemia. $N$ Engl f Med 1995;333:1301-7.

\section{Population studied was peculiarly healthy} and preoccupied with health

EDITOR,-According to Alberto Ascherio and colleagues, saturated fat may not be as dangerous with respect to coronary heart disease as commonly supposed, some of the risk being counteracted by consumption of fibre. ${ }^{1}$ As migh have been expected from the data in their table 1 , consumption of saturated fat was positively correlated with cigarette smoking $(r=0.981)$ and mean body mass index $(r=0.986)$ and negatively correlated with exercise $(r=-0.983)$, consumption of carotene $(r=-0.986)$ and vitamin $\mathrm{E}$ $(r=-0.950)$, and, curiously, alcohol consumption $(r=-0.984)$.

Could it be that the population of male health professionals in the United States is peculiarly healthy and preoccupied with health? As has been noted elsewhere, this could mislead the unwary. ${ }^{2}$ When figures from the study are 